\title{
Insights into workplace bullying: psychosocial drivers and effective interventions
}

\section{Jordi Escartín}

Department of Social Psychology, Facultad de Psicologia, Universitat de Barcelona, Passeig de la Vall d'Hebrón, Barcelona, Spain

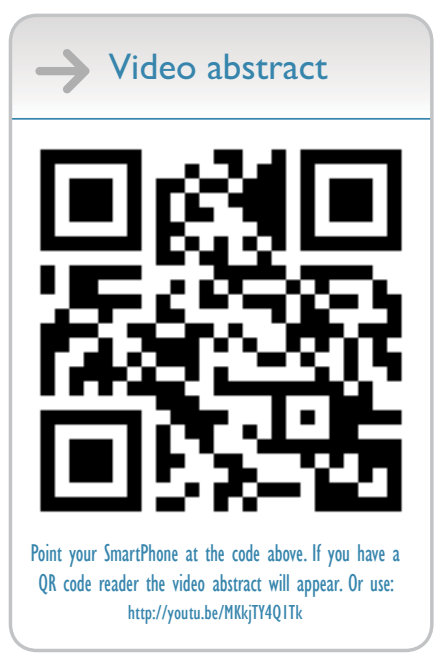

Correspondence: Jordi Escartín Department of Social Psychology, Facultad de Psicologia, Universitat de Barcelona, Passeig de la Vall d'Hebrón, I7I, 08035 Barcelona, Spain

$\mathrm{Tel}+34933125197$

Fax +34934021366

Email jordiescartin@ub.edu
This article was published in the following Dove Press journal:

Psychology Research and Behavior Management

23 June 2016

Number of times this article has been viewed

Abstract: Research on effectiveness of workplace bullying interventions has lagged behind descriptive studies on this topic. The literature on bullying intervention research has only recently expanded to a point that allows for synthesis of findings across empirical studies. This study addresses the question of whether workplace bullying can be reduced in prevalence and consequences, if so to what extent and by which strategies and interventions. It opens with a brief overview of the nature of bullying at work and discussion of some precursors and existing interventions. However, its principal focus is on the findings obtained from selected (quasi-) experimental longitudinal studies on antibullying interventions, drawing together the results of studies conducted in Europe, USA, and Australia, including several economic sectors, and concerned about primary, secondary, and tertiary prevention programs and strategies. Additional emphasis is considered from the psychosocial drivers highlighted both from prescriptive and cross-sectional studies and factual empirical studies. One randomized control study and seven quasiexperimental longitudinal studies were identified by searching electronic databases and bibliographies and via contact with experts. The majority of outcomes evidenced some level of change, mostly positive, suggesting that workplace bullying interventions are more likely to affect knowledge, attitudes, and self-perceptions, but actual bullying behaviors showed much more mixed results. In general, growing effectiveness was stated as the level of intervention increased from primary to tertiary prevention. However, methodological problems relating to the evaluation designs in most studies do not allow direct attribution of these findings to the interventions. Overall, the evaluation of antibullying interventions must flourish and be improved, requiring close cooperation between practitioners and academics to design, implement, and evaluate effective interventions based on grounded theoretical and methodological approaches. Finally, this systematic review highlights future directions for enhancing the adoption, highquality implementation, and dissemination of evidence-based workplace bullying prevention and intervention programs.

Keywords: evaluation, intervention programs, systematic review, training, violence prevention, workplace bullying

\section{Introduction}

Workplace bullying has been defined as a set of negative behaviors (eg, harassing, offending, socially excluding, or negatively affecting work tasks) directed to organizational members or their work context that occur regularly and repeatedly over a period of time. ${ }^{1}$ For the victims of these negative social behaviors, cross-sectional studies have reported that bullying can result in psychological symptoms, such as anxiety, sleep problems, depression, burnout, or increased substance use, ${ }^{2}$ and can negatively impact 
job satisfaction and affective commitment. ${ }^{3}$ Longitudinal studies have replicated these undesirable effects. ${ }^{4}$

Regarding the impact on organizations, research has shown that bullying is related to absenteeism, presenteeism, sickness absence, turnover, and other economic costs (medical costs, early retirement, etc). ${ }^{5,6}$ These consequences have also been extended to the team level, affecting the turnover intentions of those employees who had not been direct targets. ${ }^{7}$ Recent studies have shown a contagion effect where bullying from peers and supervisors was related to further negative behaviors from employees through trickle-down (superiors) and trickle sideways (peers) effects. ${ }^{8,9}$ In fact, perpetration has been demonstrated to be a consequence of victimization. ${ }^{10}$

Being aware of these widespread negative consequences, there is a need for effective interventions. ${ }^{11,12}$ Systematic knowledge about previous interventions has important implications for the development of future organizational-, team-, and individual-level interventions. It is clear that a focus on prevention and intervention efforts is pivotal to ensure the health and well-being of organizations and their employees. Therefore, adopting an evidence-based approach, ${ }^{13}$ the purpose of this systematic review was to examine the published and unpublished research on empirical experimental and quasiexperimental longitudinal interventions against bullying and to find out the main psychosocial drivers that can affect their success, hopefully facilitating the translation of research findings to practice. Such a systematic review appears relevant because evidence from a single study could produce inaccurate inferences. ${ }^{13}$

\section{Precursors of workplace bullying}

To intervene and prevent bullying behaviors and their negative consequences, their correct causes must first be identified. Scholars have argued that in order for bullying to take place, the context must allow the behavior to occur. ${ }^{3,14}$ According to the work environmental hypothesis, ${ }^{15}$ several studies have pointed out how factors beyond individual characteristics are the main causes of bullying. ${ }^{16}$ Among the different antecedents, climate has been one of the most prominently identified to explain workplace behavior. ${ }^{17}$ Recent multilevel studies have found that collective perceptions of fairness and psychosocial safety buffer bullying behaviors in work units. ${ }^{18,19}$ Similarly, nonsupportive leadership practices have been related to bullying within work units. ${ }^{20,21}$ Finally, group processes have shown an impact on the incidence and maintenance of bullying. ${ }^{22} \mathrm{~A}$ recent multilevel study revealed that, among and beyond employees' identification with their work unit, in groups with strong average levels of identification, a reduced likelihood of the occurrence of bullying was found. ${ }^{23}$

\section{Interventions against workplace bullying}

Initial studies focused on intervention strategies against bullying recommended the introduction of antibullying policies. ${ }^{24,25}$ Recent studies have shown that many organizations have created antibullying policies, although with dissimilar results. In a study focused on the use of antibullying policies in organizations, 36 interviews with Human Resources (HR) professionals from the USA were conducted and analyzed using a constructivist grounded theory approach. ${ }^{26}$ The results showed that only one of the $36 \mathrm{HR}$ professionals felt that the organization had an antibullying policy that actually used the word "bullying" and covered specific bullying activities. Of the other 35 HR professionals, 16 believed their organization had policies that addressed bullying just "indirectly", 14 believed their organization had no antibullying policies, and five did not know if their organization had policies on bullying.

Similarly, a study among 204 Finish municipalities analyzed the extent to which several intervention strategies (eg, antibullying policies, training and information, and monitoring of the work climate) were used. ${ }^{27}$ The results showed that most common measures taken were having discussions with the parties involved and consulting occupational health care services. Nevertheless, almost $75 \%$ of the municipalities delivered information about bullying to their employees and had a written antibullying policy (or were developing one) and that $\sim 25 \%$ conducted trainings for managers and supervisors on the topic of bullying. Furthermore, counseling or training was also provided to perpetrators and targets, and even transfer of either the target or the perpetrator was a moderately common policy.

Beyond these organizational policies, a German qualitative study explored which intervention strategies were actually applied by 18 external professional consultants specialized in bullying. ${ }^{28}$ Through semistructured interviews, the results showed that consultants applied several strategies, individual or simultaneously, such as conflict moderation, mediation, coaching, and/or organization development.

The previous studies mapped out primary, secondary, and tertiary prevention strategies, aimed at reducing risk of bullying. ${ }^{29}$ However, none of these studies allowed the expansion of the actual knowledge on the direct success of interventions targeted to eradicate or minimize bullying behaviors. One of the main reasons is their cross-sectional nature, which 
precludes from enhancing the understanding of the specific added value of certain strategies from the preintervention to the postintervention phase. To overcome this gap will require systematic analyses of experimental and quasiexperimental longitudinal studies, and this is exactly what was done in the present review.

\section{Psychosocial drivers}

Finding out and learning from successful interventions would predispose academics and practitioners to better invest their efforts in effective strategies. However, these efforts could not be completed without acknowledging the profound influence of the psychosocial drivers on interventions' effectiveness. The aforementioned studies have highlighted more than half-dozen psychosocial drivers that should be taken into account when addressing an intervention against bullying (Table 1). ${ }^{26,28,30}$

Again, however, these valuable contributions and prescriptive recipes are not based on actual intervention studies. Therefore, more empirical evidence of the psychosocial drivers that impact on interventions' effectiveness needs to be collected from specific factual intervention studies, especially those based on longitudinal designs.

\section{Research aims}

A UK report from the National Institute for Health Research conducted by Illing et $\mathrm{al}^{31}$ stated that "although there are promising signs of progress across the scope of interventions employed to manage workplace bullying, there is a need for a comprehensive review of evidence on bullying interventions" (p. 19). This report placed primary importance on the identification of context-mechanism-outcome configurations and included 175 articles, although just a few of them were actual interventions on bullying. From the several main goals, one was to synthesize evidence on the preventative and management interventions that address bullying interventions and inappropriate behavior. It is noticeable that their review offered evidence at three levels - the individual, the team, and the organization. ${ }^{31}$ Similarly, other previous systematic reviews have been conducted to better understand the effectiveness of bullying programs and interventions..$^{32,33}$ Such studies have also offered insightful guidance on how to proceed; however, they suffer from some limitations.

One of these reviews suffers from two major flaws. ${ }^{32}$ First, it mixed up studies on bullying and incivility. This is not a minor problem. There are several key characteristics of bullying (intensity, frequency, power, and intent) that differentiate it from other instances of workplace aggression like incivility. According to several authors, ${ }^{34}$ whereas bullying has been conceptualized as frequent, intentional, of high intensity, and perpetrated by an insider with power, incivility is of lower intensity and characterized by ambiguous intent. Therefore, these two work experiences, although simultaneously occurring, are conceptually different. And second, the studies included on such revision were mainly prescriptive, advocating intervention, but not reporting a

Table I Psychosocial drivers highlighted by prescriptive and actual empirical intervention studies

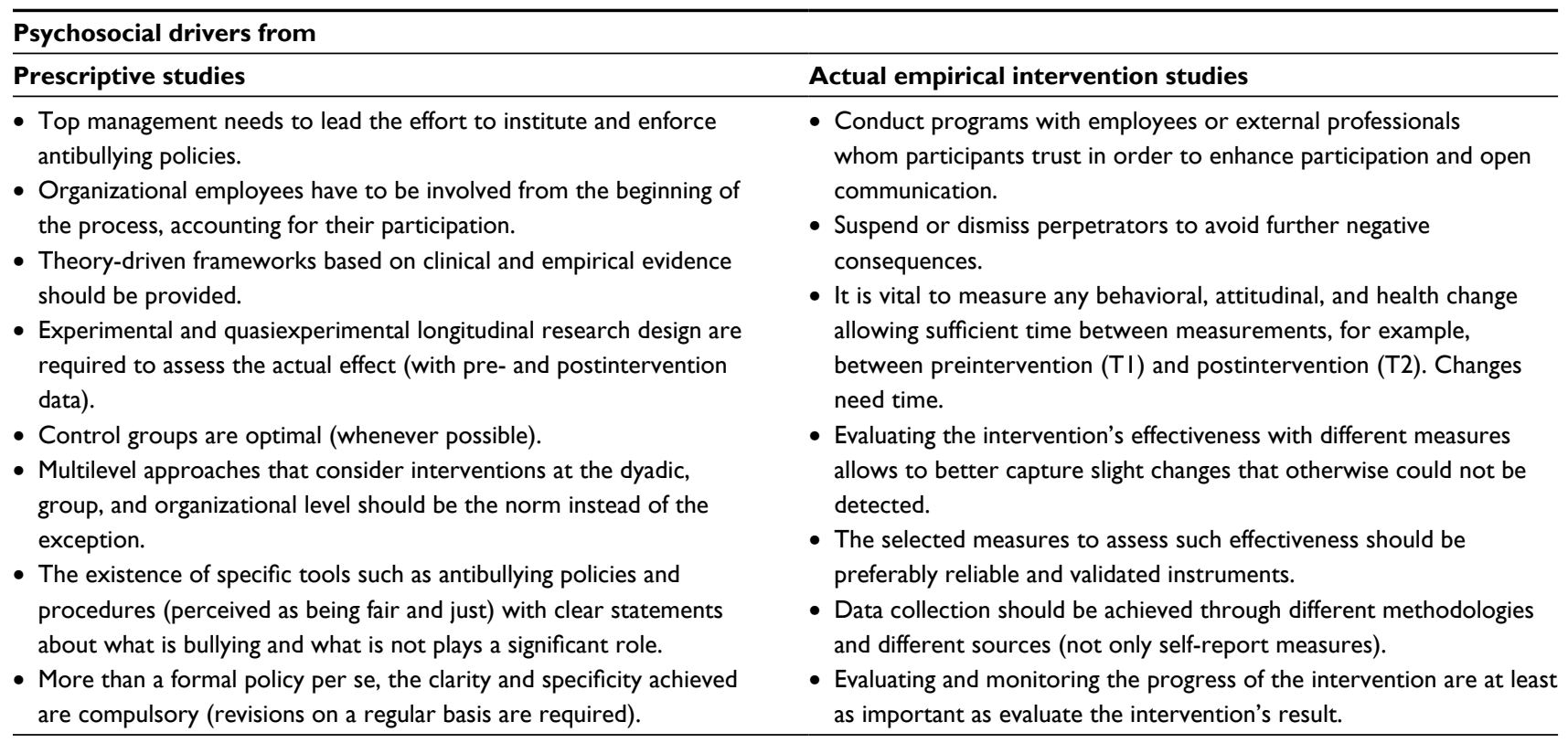


specific intervention. Because of the scarce number of published empirical studies on workplace bullying interventions, pursuing a more accurate analysis of actual interventions is worthwhile and necessary.

The second study that has offered a revision also offers room for improvement. ${ }^{33}$ First, it mixed up studies on school bullying and workplace bullying. Because of the complexity of both phenomena and the extensive literature on and tradition of school bullying interventions and meta-analytic reviews, the present study focused exclusively on the work domain. Second, their revision was dedicated equally to bullying and violence, with no clear distinction between them, neither conceptually nor empirically. And finally, the analyzed publications included original research studies, meta-analyses, and one systematic review. Acknowledging the benefits of embracing several resources and approaches, the present study concerns on revealing the impact of empirical studies on interventions conducted with longitudinal designs targeted at reducing and avoiding workplace bullying.

Therefore, listening to previous calls for more research on why and how interventions succeed, ${ }^{35}$ the present study systematically reviewed the published and unpublished experimental and quasiexperimental longitudinal studies on bullying interventions, with a close examination of the elements that hinder or facilitate desired outcomes, namely, the main psychosocial drivers.

\section{Method}

\section{Data collection}

Following Briner et al's ${ }^{13}$ procedures for systematic reviews, we focused on five consecutive steps to collect our data: framework, inclusion criteria, search strategy, screen, and study quality.

\section{Framework}

The "Intervention" component described by Denyer and Tranfield $^{36}$ from the CIMO (content, intervention, mechanisms, outcomes) framework was used in the present systematic review. Thus, our evaluation examined interventions designed to alter the health, attitudes, and/or behavior of organizational employees.

\section{Inclusion and exclusion criteria}

Studies with experimental and quasiexperimental designs with at least two waves of data (T1-T2) were included. This was a main decision to provide evidence about the effectiveness of the interventions conducted. ${ }^{37}$ To use only designs with more sound evaluations (eg, randomized control trials
[RCTs]) could have been the most desirable; however, within the bullying domain, this restriction could have led to an unaffordable sample reduction. Therefore, studies had to be longitudinal (repeated measures) and had to actually apply an intervention strategy. Studies could use both qualitative and quantitative analyses. Language and sample size restrictions were not applied.

However, studies were excluded if they focused on other forms of bullying (like school bullying) or violence (physical, sexual, etc), or involved aggressors from outside the organization (like costumers). Furthermore, studies that did not have the full text, did not report any actual intervention, employed a cross-sectional design, or were theoretical, descriptive, focused on the negative effects associated with bullying, reviews, or meta-analysis were also excluded.

\section{Search strategy}

The search strategy was based on the main academic databases such as Psycinfo, Scopus, EBSCO, Medline, and SciELO. Several search terms were used, such as "workplace bullying, mobbing, psychological harassment, psychological abuse, psychological violence", etc. These terms were crossed with other relevant keywords, such as "prevention, intervention, assessment, implementation, training", etc. Following previous suggestions about the need to avoid certain search strategy limitations ${ }^{38}$ the search also included other sources such as book chapters and technical reports available online and obtained through Google searches and Google Scholar. No time restrictions were applied, because intervention studies on workplace bullying are extremely scarce.

\section{Screening}

The inclusion and exclusion criteria were used to screen the search results, and only the studies that described intervention or prevention measures against bullying were full-text screened.

\section{Study quality}

In order to be included in the present systematic review, studies had to explicitly point out the authors' details, aims pursued, methods used, study participants and context, and intervention' success.

\section{Data analysis}

In order to synthetize the evidence of the different studies, a textual narrative synthesis was conducted. The defining characteristic of this synthesis is the adoption of a "narrative (as opposed to statistical) summary of the findings of studies 
to the process of synthesis". ${ }^{39}$ The four elements of a narrative synthesis used were identifying the theoretical model applied in the intervention studies, developing an initial description of the interventions' outcomes, identifying the relationships between the different interventions and their success, and finally, assessing the robustness of the synthesis. ${ }^{39}$ The "Results" section is structured based on these elements.

\section{Results Applied theoretical models}

The final search resulted in eight intervention studies that fulfilled all eligibility criteria, which were critically appraised, and are listed in Table 2. These studies included seven quasiexperimental longitudinal designs and one study with experimental design. The eight studies aimed at intervening against and dealing with workplace bullying through three distinct ways: primary, secondary, and tertiary interventions. Primary interventions focus on preventing occurrence of bullying in the workplace through contextual changes or employees training and educational workshops. In total, five of the eight reviewed studies conducted interventions mainly intended to enhance primary prevention. ${ }^{40-44}$ Secondary interventions aim to reduce the extent and duration of any incident of bullying and to provide employees with the necessary skills and/or coping resources to deal with bullying should it occur. Two more of the eight reviewed studies were mainly

Table 2 List of longitudinal intervention studies included in the review

\begin{tabular}{|c|c|}
\hline \multicolumn{2}{|l|}{ Study } \\
\hline Schwickerath and Zapf ${ }^{47}$ & $\begin{array}{l}\text { This study conducted an inpatient treatment on bullying victims. Descriptive analysis showed that patients who had } \\
\text { been victims of bullying were very satisfied with the therapy. Moreover, patients benefitted the most from being able } \\
\text { to set themselves new goals and values, which was an important part of the therapy in connection with the elaboration } \\
\text { of a stable perspective (motto). Thus, all patients except the unemployables profited from the treatment, even if they } \\
\text { had different base levels. For victims of bullying, the introduced program offered effective and efficient therapy, which is } \\
\text { tailored to the particular needs of this patient group. }\end{array}$ \\
\hline León-Pérez et al ${ }^{42}$ & $\begin{array}{l}\text { Using the well-known Kirkpatrick model, this study evaluated the effectiveness of a training program designed to prevent } \\
\text { workplace bullying. Specifically, conflict management training was conducted as an appropriate way to decrease conflict at } \\
\text { work and to avoid conflict escalation into a more destructive phase which could result in more extreme forms of conflict, } \\
\text { namely workplace bullying. The results suggested that the training created high levels of satisfaction and expectations that } \\
\text { the program would be successfully implemented and that participants improved their conflict management knowledge and } \\
\text { skills as well as had positive attitudes toward the training and the training objectives. Finally, there was a reduction in the } \\
\text { number of negative acts reported at work; however, this was not statistically significant. }\end{array}$ \\
\hline Hoel and Giga ${ }^{4 !}$ & $\begin{array}{l}\text { Through a randomized control design, the aim of this study was twofold: I) to devise and test the appropriateness as well } \\
\text { as effectiveness of a risk assessment tool and } 2 \text { ) to develop, implement, and evaluate three different bullying intervention } \\
\text { programs. These programs focused on training in three different areas: policy communication, stress management, and } \\
\text { negative behavior awareness. Important improvement in the desired direction as measured by a variety of variables did } \\
\text { occur for } 45 \% \text { of the experiment groups. For three of the experiment groups, scores on all relevant variables measured } \\
\text { were in the desired direction. }\end{array}$ \\
\hline Meloni and Austin ${ }^{45}$ & $\begin{array}{l}\text { This study implemented a zero tolerance of bullying and harassment program and evaluated its outcomes in the hospital. } \\
\text { After nearly } 3 \text { years, the program had a positive impact, including contributing to an overall increase in staff satisfaction } \\
\text { and improvements in the bullying and harassment (as assessed by the employee satisfaction surveys). }\end{array}$ \\
\hline Chipps and McRury ${ }^{40}$ & $\begin{array}{l}\text { This quasiexperimental pilot study was aimed at examining the effect of an educational program provided to nursing staff } \\
\text { on workplace bullying. The study concluded that the development of an educational program and use of a registered nurse } \\
\text { educator in a group setting is an effective method for addressing workplace bullying. }\end{array}$ \\
\hline Pate and Beaumont ${ }^{46}$ & $\begin{array}{l}\text { This study aimed to analyze the extent to which a comprehensive policy was successful in reducing workplace bullying. } \\
\text { The findings revealed that there was a significant reduction in perceptions of bullying in the organization. However, the } \\
\text { level of trust in the senior management was not enhanced as a result of the success. }\end{array}$ \\
\hline Stagg et $\mathrm{al}^{43}$ & $\begin{array}{l}\text { This study conducted a program to increase staff nurses' knowledge of management of workplace bullying consisting of a } \\
\text { 2-hour cognitive rehearsal training. The results showed that after the training program, nurses' knowledge of workplace } \\
\text { bullying management significantly increased. Additionally, nurses were significantly more likely to report that they had } \\
\text { observed bullying and had bullied others. Furthermore, nurses felt more adequately prepared to handle workplace } \\
\text { bullying. }\end{array}$ \\
\hline Vartia and Tehrani ${ }^{44}$ & $\begin{array}{l}\text { This study conducted a zero inappropriate and bullying behavior intervention (together with increasing and strengthening } \\
\text { the levels of positive interaction between employees). The intervention took place among school staff from eight primary } \\
\text { schools with the support and involvement of the city council. During the period of I year, the project mainly involved two } \\
\text { joint } 90 \text { minutes to 2-hour trainings and discussions. One of the main results was that employees felt that they did not } \\
\text { suffer from inappropriate behaviors at work, and therefore, no change between time I and time } 2 \text { was expected. }\end{array}$ \\
\hline
\end{tabular}


committed to enhance secondary prevention. ${ }^{45,46}$ Finally, tertiary prevention programs focus on reducing negative consequences after bullying has occurred, through victims' support and assistance. Only one of the eight reviewed studies focused on tertiary prevention. ${ }^{47}$

These studies could also be classified according to their focus on organizational or interpersonal interventions. Hoel and Giga, ${ }^{41}$ and Pate and Beaumont ${ }^{46}$ had an organizational focus, interested in developing programs, policies, and work practices to promote a safe working environment. The rest of the studies, had a more interpersonal focus, interested in employees training staff to anticipate, recognize, and respond to conflict and bullying.

Regarding the theoretical model underlying the selected intervention studies, Schwickerath and Zapf ${ }^{42}$ and LeónPérez et $a l^{47}$ explicitly stated the intervention's theoretical orientation, which was based on the conflict escalation perspective. ${ }^{48,49}$ However, the other remaining studies did not point out the theory that guided their interventions.

\section{Description of interventions \\ Design}

Seven of the eight studies used quasiexperimental designs, ${ }^{40,42-47}$ and only one used a RCT, ${ }^{41}$ which randomly allocated participants in one of the five different programs (and combinations between them) under study. Moreover, six of the longitudinal studies collected two waves of data" one preintervention (T1) and another postintervention (T2). ${ }^{40-44,46}$ However, two of the studies reported a third wave of data (T1-T2-T3). ${ }^{45,47}$ Regarding the time lag between the pretest and the posttest, all the studies varied significantly, from 4 years to 3 years, ${ }^{45,46} 1$ year, ${ }^{47} 8$ months, ${ }^{42} 7$ months, ${ }^{40}$ and 6 months. ${ }^{41}$ Finally, it is noteworthy that one of the eight reviewed studies collected the data postintervention, 2 hours after the first data point (Table 3). ${ }^{43}$

\section{Methodology}

Five of the studies used a quantitative methodology, the other three studies used a mix between quantitative and qualita-

Table 3 Description of the studies included in the review

\begin{tabular}{|c|c|c|c|c|c|c|}
\hline Study & Design & Method & Sample & Country & Research aim & Prevention \\
\hline $\begin{array}{l}\text { Schwickerath } \\
\text { and Zapf }{ }^{47}\end{array}$ & $\begin{array}{l}\text { QEL } \\
\text { TI-T2-T3; } \\
\text { I year }\end{array}$ & $\begin{array}{l}\text { QL and } \\
\text { QT }\end{array}$ & $\begin{array}{l}\text { I02 bullied patients in a } \\
\text { clinic }\end{array}$ & Germany & $\begin{array}{l}\text { To improve patients' health through } \\
\text { a 6-week cognitive behavior therapy } \\
\text { program }\end{array}$ & 3 \\
\hline $\begin{array}{l}\text { León-Pérez } \\
\text { et } \mathrm{a}^{42}\end{array}$ & $\begin{array}{l}\text { QEL } \\
\text { TI-T2; } 8 \\
\text { months }\end{array}$ & $\begin{array}{l}\text { QL and } \\
\text { QT }\end{array}$ & $\begin{array}{l}\text { Manufacturing company } \\
\text { (I } 27 \text { employees: } 42 \\
\text { trained) }\end{array}$ & Spain & $\begin{array}{l}\text { To reduce incidence of bullying } \\
\text { (conflict management strategies training) }\end{array}$ & I \\
\hline $\begin{array}{l}\text { Hoel and } \\
\text { Giga }^{41}\end{array}$ & $\begin{array}{l}\text { Randomized } \\
\text { control trial } \\
\text { TI-T2; } 6 \\
\text { months }\end{array}$ & $\begin{array}{l}\text { QL and } \\
\text { QT }\end{array}$ & $\begin{array}{l}5 \text { organizations - health } \\
\text { sector - ( } 4 \text { experimental } \\
\text { groups and I control } \\
\text { group) }(\mathrm{N}=\text { from } 884 \text { to } \\
\mathrm{I}, 04 \mathrm{I} \text {; but } 150 \text { trained). } \\
55 \text { focus groups }(\mathrm{N}=272)\end{array}$ & UK & $\begin{array}{l}\text { To develop, implement, and evaluate } \\
\text { the effectiveness of organizational } \\
\text { interventions to prevent and manage } \\
\text { bullying: policy communication (only), } \\
\text { stress (and policy communication), } \\
\text { negative behavior awareness (and policy } \\
\text { communication), and a combination } \\
\text { of all. }\end{array}$ & I \\
\hline $\begin{array}{l}\text { Meloni and } \\
\text { Austin }^{45}\end{array}$ & $\begin{array}{l}\text { QEL } \\
\text { TI-T2-T3; } \\
3 \text { years }\end{array}$ & QT & $\begin{array}{l}\text { Hospital employees }(\mathrm{N}= \\
\text { from } 421 \text { to } 710) \\
\text { Antibullying training } \\
(\mathrm{N}=52) \\
\text { Zero tolerance program } \\
(\mathrm{N}=20)\end{array}$ & Australia & $\begin{array}{l}\text { To I) increase awareness of bullying } \\
\text { through a training program, 2) educate } \\
\text { employees about bullying, and 3) develop } \\
\text { a zero-tolerance culture. }\end{array}$ & 2 \\
\hline $\begin{array}{l}\text { Chipps and } \\
\text { McRury }{ }^{40}\end{array}$ & $\begin{array}{l}\text { QEL pilot } \\
\text { study TI-T2; } \\
7 \text { months }\end{array}$ & QT & 16 staff nurses & USA & $\begin{array}{l}\text { To examine the effect of an educational } \\
\text { program on the incidence of bullying }\end{array}$ & I \\
\hline $\begin{array}{l}\text { Pate and } \\
\text { Beaumont }{ }^{46}\end{array}$ & $\begin{array}{l}\text { QEL } \\
\text { TI-T2; } 4 \text { years }\end{array}$ & QT & $\begin{array}{l}200 \text { employees from a } \\
\text { public sector organization }\end{array}$ & UK & $\begin{array}{l}\text { To examine the extent to which } \\
\text { an antibullying policy reduces the } \\
\text { perception of bullying }\end{array}$ & 2 \\
\hline Stagg et $\mathrm{a}^{43}$ & $\begin{array}{l}\text { QEL } \\
\text { TI-T2; } 2 \text { hours }\end{array}$ & QT & $\begin{array}{l}62 \text { medical and surgical } \\
\text { staff nurses (only I } 5 \text { in } \\
\text { rehearsal program }\end{array}$ & USA & $\begin{array}{l}\text { To evaluate the effectiveness of a } \\
\text { training program on cognitive rehearsal } \\
\text { on bullying management }\end{array}$ & I \\
\hline $\begin{array}{l}\text { Vartia and } \\
\text { Tehrani }^{44}\end{array}$ & $\begin{array}{l}\text { QEL } \\
\text { TI-T2 }\end{array}$ & QT & $\begin{array}{l}318 \text { primary school } \\
\text { employees }\end{array}$ & Finland & $\begin{array}{l}\text { To decrease bullying and increase } \\
\text { employees' awareness through } \\
\text { educational programs }\end{array}$ & I \\
\hline
\end{tabular}

Notes: QEL, quasiexperimental longitudinal research design; TI, time I; QL, qualitative; QT, quantitative; prevention (I, primary; 2, secondary; 3, tertiary). 
tive methodology. No intervention study used exclusively a qualitative approach.

\section{Sample and country}

These details are provided in Table 3 .

\section{Research aim}

Five of the studies were intended to minimize the incidence or perception of workplace bullying after training and education. ${ }^{40-44,46}$ Two other studies aimed to enhance employees' psychological health and well-being, with therapy for bullying victims and training for organizational employees. ${ }^{41,47}$ Finally, Meloni and Austin ${ }^{45}$ and Stagg et al ${ }^{43}$ proposed to enhance employees' management skills against bullying through training programs. Therefore, except the victims' study that used cognitive-behavior therapy, ${ }^{47}$ the rest of the studies used training and education as the main intervention strategy. Of course, such training and education strategies differed significantly in content and duration between the different reviewed studies.

\section{Success of interventions}

The intervention programs of most of the studies but one $e^{47}$ were based on trainings (Table 4). Of these cases, most of the studies defined the trainer as "expert", but did not clarify whether the research or the organization (or external) staff

Table 4 Measures and main results of the studies included in the review

\begin{tabular}{|c|c|c|c|c|}
\hline Study & Intervention program & Measures & $\begin{array}{l}\text { Dependent } \\
\text { variable }\end{array}$ & Main results \\
\hline $\begin{array}{l}\text { Schwickerath } \\
\text { and Zapf }{ }^{47}\end{array}$ & $\begin{array}{l}\text { Inpatient bullying therapy } \\
\text { (6-week cognitive behavior } \\
\text { therapy program) }\end{array}$ & $\begin{array}{l}\text { Beck's Depression } \\
\text { Inventory }\end{array}$ & $\begin{array}{l}\text { Ability to come back } \\
\text { to work. } \\
\text { Depressive } \\
\text { symptomatology. }\end{array}$ & $\begin{array}{l}\text { Significant reduction of complaints caused by } \\
\text { different health symptoms, depressive moods, and } \\
\text { psychosomatic complaints. Significantly lower rate } \\
\text { of disability. All patients except the unemployables } \\
\text { profited from the treatment. }\end{array}$ \\
\hline $\begin{array}{l}\text { León-Pérez } \\
\text { et } \mathrm{al}^{42}\end{array}$ & $\begin{array}{l}\text { Conflict management } \\
\text { training (three sessions, } \\
\text { each lasting } 4 \text { hours and } \\
\text { follow-up session) }\end{array}$ & $\begin{array}{l}\text { COPSOQ- } \\
\text { ISTAS2I. } \\
\text { Interpersonal } \\
\text { conflict at work. } \\
\text { NAQ-R } \\
\text { GHQ-I2 }\end{array}$ & $\begin{array}{l}\text { Conflict } \\
\text { management skills. } \\
\text { Bullying prevalence. }\end{array}$ & $\begin{array}{l}\text { Most subordinates reported that their superiors } \\
\text { improved their CMS. } \\
\text { Number and intensity of interpersonal conflicts } \\
\text { significantly reduced. } \\
\text { Reduction in the number of negative acts reported at } \\
\text { work; however, this was not statistically significant. }\end{array}$ \\
\hline $\begin{array}{l}\text { Hoel and } \\
\text { Giga }^{41}\end{array}$ & $\begin{array}{l}\text { Groups: policy } \\
\text { communication (PC) } \\
\text { ( } 90 \text { minutes). } \\
\text { Stress (and PC) ( } 3 \text { hours). } \\
\text { Negative behavior } \\
\text { awareness (and PC) } \\
\text { ( } 3 \text { hours). } \\
\text { All }\end{array}$ & $\begin{array}{l}\text { NAQ-R and } \\
\text { definition } \\
\text { GHQ-I2 } \\
\text { Absenteeism } \\
\text { Intention to quit } \\
\text { Turnover } \\
\text { Satisfaction }\end{array}$ & $\begin{array}{l}\text { Bullying prevalence } \\
\text { (targets and victims). } \\
\text { Intervention } \\
\text { programs efficacy. }\end{array}$ & $\begin{array}{l}\text { No effects on the prevalence of bullying. Improvement } \\
\text { on health and well-being variables for all experimental } \\
\text { groups. Impossible to conclude that any particular } \\
\text { intervention or combination of interventions is more } \\
\text { effective than any other. }\end{array}$ \\
\hline $\begin{array}{l}\text { Meloni and } \\
\text { Austin }{ }^{45}\end{array}$ & $\begin{array}{l}\text { Zero tolerance of } \\
\text { bullying program and } \\
\text { comprehensive training }\end{array}$ & $\begin{array}{l}\text { Satisfaction } \\
\text { survey (bullying } \\
\text { questions) }\end{array}$ & $\begin{array}{l}\text { Employees' } \\
\text { satisfaction and } \\
\text { awareness. }\end{array}$ & $\begin{array}{l}\text { Employees knew how to report bullying issues and } \\
\text { also knew about the support mechanisms available. } \\
\text { Higher level of trust that these issues will be addressed } \\
\text { appropriately. Higher level of employee engagement. } \\
\text { Number of formal complaints received by HR } \\
\text { remained constant. }\end{array}$ \\
\hline $\begin{array}{l}\text { Chipps and } \\
\text { McRury }\end{array}$ & $\begin{array}{l}\text { Educational program } \\
\text { ( } 3 \text { months) }\end{array}$ & $\begin{array}{l}\text { NAQ-R and } \\
\text { definition }\end{array}$ & $\begin{array}{l}\text { Prevalence of } \\
\text { bullying }\end{array}$ & $\begin{array}{l}\text { Increase in the number of targets. } \\
\text { Decrease in the number of victims. }\end{array}$ \\
\hline $\begin{array}{l}\text { Pate and } \\
\text { Beaumont }{ }^{46}\end{array}$ & $\begin{array}{l}\text { Bullying policy and training } \\
\text { programs }\end{array}$ & Attitude survey & $\begin{array}{l}\text { "Is bullying a } \\
\text { problem in the } \\
\text { organization?" }\end{array}$ & Decline in perceptions of bullying. \\
\hline Stagg et $\mathrm{al}^{43}$ & $\begin{array}{l}\text { Rehearsal training program } \\
\text { ( } 2 \text { hours) }\end{array}$ & $\begin{array}{l}\text { Workplace } \\
\text { bullying inventory }\end{array}$ & $\begin{array}{l}\text { Attitude toward } \\
\text { bullying. Confidence } \\
\text { in defending oneself. }\end{array}$ & $\begin{array}{l}\text { Nurses felt more adequately prepared to handle } \\
\text { bullying. }\end{array}$ \\
\hline $\begin{array}{l}\text { Vartia and } \\
\text { Tehrani }{ }^{44}\end{array}$ & $\begin{array}{l}\text { Educational training } \\
\text { program to reduce bullying } \\
\text { and strengthen positive } \\
\text { interactions }\end{array}$ & NAQ-R & $\begin{array}{l}\text { Bullying prevalence. } \\
\text { Employees' } \\
\text { awareness. }\end{array}$ & $\begin{array}{l}\text { Decrease targeted and observed bullying behaviors. } \\
\text { Increased bullying awareness. }\end{array}$ \\
\hline
\end{tabular}

Abbreviations: NAQ-R, Negative Acts Questionnaire-Revised; GHQ, General Health Questionnaire; COPSOQ-ISTAS2I, Copenhagen Psychosocial Questionnaire; CMS, conflict management skill; HR, human resources. 
was the source of these trainings. Similarly, regarding fidelity to the training sessions, information was generally scarce. Most studies did not mention fidelity to the intervention at all.

\section{Measures}

Most of the studies that assessed bullying behaviors used the Negative Acts Questionnaire-REVISED, ${ }^{40-42,44}$ although one used the Workplace Bullying Inventory survey, ${ }^{43}$ or a single or several ad hoc items. ${ }^{45,46} \mathrm{~A}$ definition of bullying to asses perceived victimization was as well used. ${ }^{40,41,43}$ In addition to bullying, the intervention studies measured several well-being and health-related variables (GHQ-12 $2^{41,42}$ ), such as depression or satisfaction. ${ }^{41,47}$ Also, the Bullying Risk Assessment Tool and other variables such as psychological contract, absenteeism, intention to quit, or turnover were evaluated in the RCT study. ${ }^{41}$ Finally, several work conditions (COPSOQ-ISTAS21) and conflict management strategies were also considered. ${ }^{42}$

\section{Dependent variable}

León-Pérez et $\mathrm{al}^{42}$ asked the subordinates of the managers who received the training whether they perceived their superiors had improved their conflict management skills. The rest of the studies used self-reported data. Stagg et al ${ }^{43}$ directly asked the participants about their improvement in conflict management skills. Hoel and Giga ${ }^{41}$ evaluated whether their intervention strategies, individually or combined, had a positive effect on the prevalence of bullying and on several health-related variables. Similarly, Chipps and McRury ${ }^{40}$ and Pate and Beaumont ${ }^{46}$ assessed the bullying prevalence or relevance. Vartia and Tehrani ${ }^{44}$ measured the bullying prevalence and the employees' awareness. Similarly, Meloni and Austin ${ }^{45}$ evaluated employees' awareness and satisfaction. Finally, Schwickerath and $\mathrm{Zapf}^{47}$ tested the clinic patients' ability to come back to work after the therapy, and they also assessed their depression levels.

\section{Main results}

Five of the intervention studies claimed that their interventions were successful. Schwickerath and $\mathrm{Zapf}^{47}$ showed a significant improvement on patients' quality of life. Meloni and Austin $^{45}$ showed that employees were more satisfied, aware of the bullying issue, and empowered to confront it. Stagg et $\mathrm{al}^{43}$ got similar results and found that participants felt ready to handle bullying situations adequately. Pate and Beaumont ${ }^{46}$ evidenced a decrease in perceptions of bullying. And Vartia and Tehrani ${ }^{44}$ showed both a decrease in bullying behaviors and an increase in bullying awareness. The last three studies got mixed results, being only partially successful. León-Perez et $\mathrm{al}^{42}$ indicated that managers enhanced their conflict management skills, and that in the work context, less and minor interpersonal conflicts occurred. However, the bullying prevalence did not decrease. Hoel and Giga ${ }^{41}$ found no effects on the prevalence of bullying after the intervention. However, it was successful in improving health indicators on all four experimental groups (although without being able to distinguish which group was more effective). Finally, Chipps and $\mathrm{McRury}{ }^{40}$ showed opposite results for targets (an increase of prevalence) and victims (a decrease of prevalence). The authors discussed that the intervention allowed employees to identify negative behaviors, yet there could be reticence and shame associated with acknowledging that one has been a bullying victim.

\section{Psychosocial drivers}

The reviewed studies have truly contributed to expand the knowledge about the impact of several intervention strategies against workplace bullying. Furthermore, they have also offered empirical evidence of the psychosocial drivers that play a significant role in the intervention's process and outcomes. Table 1 (right column) lists the main psychosocial drivers outlined by these experimental and quasiexperimental longitudinal intervention studies. This list expands the aforementioned success factors (right column from Table 1) extracted from the prescriptive studies that advocate intervention (although not reporting one themselves).

\section{Robustness of the synthesis}

Following Rodgers et al, ${ }^{39}$ all eight studies were judged as relevant because they were selected for relevance early in the review by the application of inclusion criteria. However, of the eight longitudinal studies, only Hoel and Giga ${ }^{41}$ study was considered of "high" quality because it conducted a RCT, providing the most robust evidence of whether a causal relationship exists between an intervention and the outcome. The rest of the studies could be considered from "low" to "medium" quality, as they provided pre- and posttest survey results (although differences between them exist). Nevertheless, these studies are the easiest to conduct, and most of the time, more appropriate to apply given the pervasive and complex nature of workplace bullying.

\section{Discussion}

To summarize briefly the results of this systematic review, meaningful positive effects for workplace bullying interventions across the eight studies were found for most of the 
outcome variables, demonstrating promising results. Also in alignment with most scientific and professional bullying literature, the current most-applied response was primary prevention. ${ }^{1}$ This a good sign of the match between ethical and economical values guiding decision-making processes within the organizational domain. This evidence illuminates promising opportunities to reduce workplace bullying and to increase awareness across sectors.

Nevertheless, it is necessary to mention that comparing these eight empirical studies carried out for different purposes, with different methodologies and strategies, and in different organizational circumstances and cultural contexts, is not without limitations. The fact that these studies differ in their approach to the measurement as well as their selection of interventions and outcome variables limits cross-study comparability. Whenever possible, future studies should facilitate cross-study comparisons with the ones presented here. In a cumulative manner, future evidence from similar studies would allow for quantitative syntheses (meta-analyses) of results through different approaches (eg, 95\% confidence intervals, standardized mean differences, etc).

As well as applying international scientific standards, intervention studies should be comprehensive, integrated, and responsive to local conditions. First, interventions should be comprehensive. Narrowly focused interventions may limit value by neglecting other gaps within organizations. For example, an initiative to train employees is unlikely to succeed if those individuals are continually exposed to organizational contexts with lack of clarity and structure or insufficient equipment, etc. Second, interventions should be integrated, adopting a systemic approach that takes into consideration that changes in one area or process of the organization are likely to affect other areas or processes. In that sense, interventions should take place considering simultaneously the different levels (eg, individual, team, and organization). ${ }^{28}$ Finally, interventions should be locally responsive, reflecting the engagement of organizational leaders and employees, and enhancing all stakeholders' participation. Thus, intervention contents should be relevant and tailored to the specific context.

\section{Avenues for future research}

A majority of these interventions were implemented in the health sector (five out of eight), possibly as a result of the widespread occurrences of bullying in those settings. ${ }^{50}$ Nevertheless, future studies should focus on assessing interventions against workplace bullying in different sectors to make possible the generalization of the present conclusions.
These results allow us to cautiously conclude that there is evidence supporting the effectiveness of bullying interventions in enhancing employees' awareness and knowledge of effective practices, skills, feelings of efficacy, and actual behaviors in responding to incidences of workplace bullying. The prudent nature of these conclusions is because of the fact that the majority of studies were not theory driven, did not had a control group within their evaluation designs, used self-reported data, and were mainly conducted within the European context. Consequently, causal conclusion cannot be completely assured.

The effects may simply be an artifact of the employees' reaction and motivation to the interventions and not a true indicator of the interventions' effectiveness. Although there are logical concerns related to waiting-list control groups, future studies could include them assuring the maximum level of ethical concerns. ${ }^{51}$ Regarding the collection of information, self-report measures could have led to response inflation because of common method variance and social desirability. ${ }^{52,53}$ For this reason, it is advisable that evaluations incorporate data from a variety of sources, in an attempt to "triangulate" information. ${ }^{54}$ Future studies, using different types of procedures for collecting data and obtaining that information through different sources - mixed-method approaches - could augment the validity and reliability of their data and their interpretation. Also, more intervention studies in the USA and Australia, but also in different parts of the world, such as Central and South America, Africa, and Asia, are required to improve the generalizability of the results. ${ }^{55}$

A bias in favor of interpersonal interventions in comparison to organizational interventions was found. Within the former, only training appeared to be the preferred strategy, and we were able to find any intervention study that applied other strategies such as mediation or coaching. ${ }^{28,56}$ In relation to that, most of the training programs used only one technique as intervention strategy, which renders comparison between them difficult. Future studies that offer cost-benefit analyses for investing in certain types of intervention strategies are required. Moreover, contents and/or syllabus regarding the specific trainings were not described in detail, and thus manifested low descriptive validity.

The preferred longitudinal design within most of the intervention studies included only two waves of data. It affected not only the causal nature of the conclusions that could be inferred but also the knowledge available regarding the length of the follow-ups. For instance, in one study, the collection of outcome data took place immediately on program completion, which could compromise the intervention 
effect (with a false-positive). Nevertheless, most of the studies collected data more than 6 months after the intervention program had concluded, which is in line with most bullying conceptualizations. ${ }^{15}$ Future studies collecting several data points should enable better understanding of the optimal length of the follow-up for the different outcome variables (because health and well-being changes can be different to cognitive, emotional, and behavioral modifications). Of course, diary studies that collect several data points each day could better inform of the intrinsic dynamics involved in within-individual learning processes and generalizations of the interventions' success. Similarly, the duration of the interventions varied significantly, being most of them of a few hours within 1 day. This fact questions the obtained results and points out on the relevance of the optimal length of the interventions. Future studies should also address this concern.

Regarding the participants, two different issues should be highlighted and challenged in the future. First, in most of the studies, there was a discrepancy between the number of participants in the intervention programs (training) and the total number of participants who participated in the study. The researchers' decisions regarding the number of employees trained could have affected the intervention results, probably diminishing the effects on emotional, cognitive, and behavioral patterns. ${ }^{41}$ Second, the representativeness of the samples was not an issue covered in most studies, which threatens the generalizability of the interventions' success. ${ }^{57}$

With regard to the content of the success measures, data varied significantly between the reviewed studies, but no study collected objective data from the organization (absenteeism, presenteeism, sickness absence, turnover, etc). In other words, it is also crucial to make use of more objective measures (data that can be validated by others), such as managerial reports and scores from third parties. ${ }^{58}$

\section{Practical implications}

The reviewed studies shed light on the benefits of training programs focused on educating employees and on developing their skills to handle bullying effectively. Therefore, organizations and HR managers who are keen on reducing workplace bullying should rely on these empirical results. This is especially true when taking into account the several psychosocial drivers stressed in the descriptive and empirical literature. Thus, it is advisable to have facilitators (internal or external) who are respected and trusted by employees. The managers, the leaders, and the organization itself have to be perceived as committed and involved in such antibullying interventions (eg, zero-tolerance policies with clear procedures), and a positive climate has to be developed.

\section{Best practices}

The reviewed tertiary prevention study from Schwickerath and Zapf ${ }^{47}$ offered several "best practices" to help clinical psychologists and professionals aid victims of workplace bullying. These include strategies to take distance from the negative situation, solve problems, and address the need for interpersonal skills to manage stress and conflicting situations, and occupational and sports therapies. Moreover, during the therapy process, it is desirable to understand the phenomenon experienced and to visualize the future with hope.

Regarding the two intervention studies focused on secondary prevention, ${ }^{45,46}$ the following "best practices" should be remarked: informal intervention first whenever possible, workplace bullying information resources available through the organization, continuous feedback between the different hierarchical positions, zero tolerance against bullying programs (also included in the contract for newcomers), continuous opportunities for networking and internal communication, and strategies to improve assertive communication.

Finally, the rest of the reviewed studies focused on primary intervention programs, which offered several "best practices" for organizations and professionals: mentoring, coaching, and mediation; creation of a formal committee to handle future bullying cases; clarity on the antibullying policies regarding what it is and what is not; and processes to detect, manage, and prevent bullying situations. Special mention should be given to training because training evaluation was the rule rather than the exception when intervening against workplace bullying within our reviewed studies. ${ }^{59}$ One of the reviewed studies adopted Kirkpatrick's evaluation model, ${ }^{60}$ which is structured around four levels, each measuring complementary aspects of a training course (reaction, learning, behavior, and results). León-Pérez et $\mathrm{al}^{42}$ considered the impact of training through peer and self-assessment. We advocate for the utilization of this or similar models to evaluate training programs and their impact at organizational, interpersonal, and individual levels.

\section{Final remarks}

Not all reviewed interventions were clearly successful. Chipps and McRury ${ }^{40}$ found an increase of bullying prevalence after their intervention, and two more studies found no differences at all, ${ }^{41,42}$ which could be related to iatrogenic effects, parallel to the similar ones found within the school 
bullying domain. ${ }^{61}$ We subscribe that being aware of and mitigating these possible effects seem at least as important as generating successful interventions against bullying. ${ }^{62}$ In relation to that the evolution of expert professional consultancy as an activity involved in managing antibullying intervention programs have raised some concerns (such as scapegoating from the organizational side or theoretical background from the consultant side). ${ }^{63}$ Therefore, we argue for a more cautious and critical approach into the role of such consultant professionals, because the best of ideas can have unintended consequences. Moreover, it is necessary to assess the intervention costs (economically and derived from other resources, like time). Such generalized practice could allow comparisons of the costs and cost-benefit ratios of various intervention programs, which could be useful to organizations and practitioners selecting them. The final purpose then is not to spend more resources (money), but spend them better.

Finally, since workplace bullying is relatively a lowfrequency phenomenon (in comparison with other forms of counterproductive work behaviors, like incivility) ${ }^{34}$ but with contagious effects, ${ }^{8,9}$ it is susceptible to so-called "black swans" (defined as low-probability, high-impact events), ${ }^{64}$ which means that when happens, it has severe and interdependent consequences (side effects) among the directly and indirectly affected employees and among the whole organization. A recent study has calculated the burden on workers' quality of life and productivity associated with workplace bullying and found that the adjusted marginal overall productivity cost ranged from $\sim 15 \%$, corresponding to Italian Purchase Power Parity 2010, which amounted to US\$4,182-5,236 yearly. ${ }^{65}$ Thus, the question is, how is a given department affected when a bully perpetrates negative behaviors but the direct supervisor does nothing, legitimating then the bullying process? And how is the whole organization impacted? A previous study focused on complexity science have showed the existence of nonlinear effects. ${ }^{10}$ Therefore, in line with the empirical intervention studies reviewed here, most efforts should continue being directed to understand and anticipate the negative consequences of workplace bullying, mainly through primary intervention policies, procedures, programs, and structures. These, when settled in a flexible manner that allows change and revision over time, have been shown to not enable, motivate, and precipitate bullying behaviors. ${ }^{66}$ Thus, newcomers could have available information regarding the organizational culture on bullying (ie, zero-tolerance policy), employees who start coping with interpersonal conflicts at work could constantly benefit from continuous training (ie, conflict management skills), and those employees who feel affected by bullying could have clear instructions on who, how, where, and when confront the situation (formal procedure in bullying cases).

\section{Conclusion}

This study represents a comprehensive attempt to provide a systematic review of interventions against workplace bullying worldwide, aiming to shed light on the necessary features for developing stronger and more useful connections between theory, methods, and practice. ${ }^{67}$ We examined whether the empirical evidence from (quasi-) experimental longitudinal studies supported the effectiveness of several primary, secondary, and tertiary prevention programs and strategies. We also highlighted the psychosocial drivers that facilitate or challenge such effectiveness. Our findings represent inspiring opportunities for organizations and HR managers committed to prevent and eradicate bullying behaviors and their negative consequences. We recognize that evaluation research on workplace bullying programs is still at an early stage and needs to be addressed sooner than later. Therefore, our conclusions encourage conducting more and more complex interventions. $^{68}$

\section{Acknowledgements}

This work was sponsored by the Ministry of Economy and Competitiveness under Grant PSI2013-41865-P.

\section{Disclosure}

The author reports no conflicts of interest in this work.

\section{References}

1. Einarsen S, Hoel H, Zapf D, Cooper CL. Bullying and Harassment in the Workplace: Developments in Theory, Research and Practice. 2nd ed. London \& New York: Taylor \& Francis; 2011.

2. Nielsen MB, Einarsen S. Outcomes of exposure to workplace bullying: a meta-analytic review. Work Stress. 2012;26(4):309-332.

3. Hershcovis MS, Barling J. Towards a multi-foci approach to workplace aggression: a meta-analytic review of outcomes from different perpetrators. J Organ Behav. 2010;31(1):24-44.

4. Verkuil B, Atasayi S, Molendijk ML. Workplace bullying and mental health: a meta-analysis on cross-sectional and longitudinal data. PLoS One. 2015;10(8): 0135225.

5. Hoel H, Sheehan MJ, Cooper CL, Einarsen S. Organisational effects of workplace bullying. In: Einarsen S, Hoel H, Zapf D, Cooper CL, editors. Workplace Bullying: Developments in Theory, Research and Practice. London \& New York: Taylor \& Francis; 2011:129-148.

6. McTernan WP, Dollard MF, LaMontagne AD. Depression in the workplace: an economic cost analysis of depression-related productivity loss attributable to job strain and bullying. Work Stress. 2013;27(4):321-338.

7. Houschman M, O'Reilly J, Robinson S, Wolff A. Escaping bullying: the simultaneous impact of individual and unit-level bullying on turnover intentions. Hum Relat. 2012;65(7):901-918. 
8. Aubé C, Rousseau V. Counterproductive behaviors. Group phenomena with team-level consequences. Team Perform Manag. 2014;20(5/6):202-220.

9. Mawritz MB, Mayer DM, Hoobler JM, Wayne SJ, Marinova SV. A trickle-down model of abusive supervision. Pers Psychol. 2012;65(2):325-357.

10. Escartín J, Ceja L, Navarro J, Zapf D. Modeling workplace bullying behaviors using catastrophe theory. Nonlinear Dynamics Psychol Life Sci. 2013;17(4):493-515.

11. Escartín J, Zapf D, Rodríguez-Carballeira Á. Mobbing o acoso psicológico en el trabajo. Madrid, Spain: Editorial Síntesis; 2012.

12. Leiter MP, Laschinger HK, Day A, Oore D. The impact of civility interventions on employee social behavior, distress and attitudes. J Appl Psychol. 2011;96(6):1258-1274.

13. Briner RB, Denyer D, Rousseau DM. Evidence-based management: concept cleanup time? Acad Manag Perspect. 2009;23(4):19-32.

14. Ceja L, Escartín J, Rodríguez-Carballeira Á. Organizational contexts that foster positive behavior and well-being: a comparison between familyowned firms and non-family business. Rev Psychol Soc. 2012;27(1):69-84.

15. Leymann $\mathrm{H}$. The content and development of mobbing at work. Eur J Work Org Psychol. 1996;5(2):165-184.

16. Bowling NA, Beehr TA. Workplace harassment from the victim's perspective: a theoretical model and meta-analysis. J Appl Psychol. 2006;91(5):998-1012.

17. Schneider B, Ehrhart MG, Macey WH. Organizational climate and culture. Annu Rev Psychol. 2013;64:361-388.

18. Law R, Dollard MF, Tuckey MR, Dormann C. Psychosocial safety climate as a lead indicator of workplace bullying and harassment, job resources, psychological health and employee engagement. Accid Anal Prev. 2011;43(5):1782-1793.

19. Priesemuth M, Arnaud A, Schminke M. Bad behavior in groups: the impact of overall justice climate and functional dependence on counterproductive work behavior in work units. Group Organ Manage. 2013;38(2):230-257.

20. Hauge LJ, Einarsen S, Knardahl S, Lau B, Notelaers G, Skogstad A. Leadership and role stressors as departmental level predictors of workplace bullying. Int J Stress Manage. 2011;21:453-468.

21. Skogstad A, Torsheim T, Einarsen S, Hauge LJ. Testing the work environment hypothesis of bullying on a group level of analysis: psychosocial factors as precursors of observed workplace bullying. Appl Psychol. 2011;60(3):475-495.

22. Ramsay S, Troth A, Branch S. Workplace bullying: a group processes framework. J Occup Organ Psychol. 2011;84(4):799-816.

23. Escartín J, Ullrich J, Zapf D, Schlüter E, van Dick R. Individual and group level effects of social identification on workplace bullying. Eur J Work Org Psychol. 2013;22(2):182-193.

24. European Agency for Safety and Health at Work. Bullying at work. Fact sheet 23. 2002. Available from: https://osha.europa.eu/en/publications/ factsheets/23/view. Accessed on May 5, 2016.

25. Richards J, Daley H. Bullying policy: development, implementation and monitoring. In: Einarsen S, Hoel H, Zapf D, Cooper C, editors. Bullying and Emotional Abuse in the Workplace: International Perspectives in Research and Practice. London: Taylor \& Francis; 2003:247-258.

26. Cowan RL. Yes, we have an anti-bullying policy, but ... ": HR professionals' understandings and experiences with workplace bullying policy. Commun Stud. 2011;62(3):307-327.

27. Salin D. The prevention of workplace bullying as a question of human resource management: measures adopted and underlying organizational factors. Scand J Manag. 2008;24(3):221-231.

28. Saam NJ. Interventions in workplace bullying: a multilevel approach. Eur J Work Org Psychol. 2010;19(1):51-75.

29. Hogh A, Viitasara E. A systematic review of longitudinal studies of nonfatal workplace violence. Eur JWork Org Psychol. 2005;14(3):291-313.

30. Branch S, Murray J. Building relationships and resilience in the workplace: construction of a workplace bullying training program. Paper presented at: Australia and New Zealand Academy of Management 22nd ANZAM Conference 2008: Managing in the Pacific Century, The University of Auckland, Auckland, New Zealand.
31. Illing JC, Carter M, Thompson NJ, et al. Evidence synthesis on the occurrence, causes, consequences, prevention and management of bullying and harassing behavior to inform decision making in the NHS. Final report. NIHR Service Delivery and Organisation Programme; 2013. Available from: http://goo.gl/Ypp372. Accessed April 4, 2016.

32. Hodgins M, MacCurtain S, Mannix-McNamara P. Workplace bullying and incivility: a systematic review of interventions. Int $J$ Workplace Health Manag. 2014;7(1):54-72.

33. Stagg SJ, Sheridan D. Effectiveness of bullying and violence prevention programs: a systematic review. AAOHN J. 2010;58(10):419-424.

34. Hershcovis MS. Incivility, social undermining, bullying...oh my!”: a call to reconcile constructs within workplace aggression research. J Organ Behav. 2011;32:499-519.

35. Nielsen K, Abildgaard JS. Organizational interventions: a researchbased framework for the evaluation of both process and effects. Work Stress. 2013;227(3):278-297.

36. Denyer D, Tranfield D. Producing a systematic review. In: Buchanan DA, Bryman A, editors. The SAGE Handbook of Organizational Research Methods. London, England: Sage; 2009:671-689.

37. Petticrew M, Roberts H. Systematic Reviews in the Social Sciences: A Practical Guide. Hoboken, NJ: Wiley-Blackwell; 2008.

38. Greenhalgh T, Peacock R. Effectiveness and efficiency of search methods in systematic reviews of complex evidence: audit of primary sources. BMJ. 2005;5(331):1064-1065.

39. Rodgers M, Sowden A, Petticrew M, et al. Testing methodological guidance on the conduct of narrative synthesis in systematic reviews effectiveness of interventions to promote smoke alarm ownership and function. Evaluation. 2009;15(1):47-71.

40. Chipps EM, McRury M. The development of an educational intervention to address workplace bullying: a pilot study. J Nurses Staff Dev. 2012;228(3):94-98.

41. Hoel H, Giga SI. Destructive Interpersonal Conflict in the Workplace: The Effectiveness of Management interventions. Report for the BOHRF. Manchester, England: Manchester Business School; 2006.

42. León-Pérez JM, Arenas A, Griggs TB. Effectiveness of conflict management training to prevent workplace bullying. In: Tehrani N, editor. Workplace Bullying: Symptoms and Solutions. London \& New York: Routledge; 2012:230-243.

43. Stagg SJ, Sheridan D, Jones RA, Speroni KG. Evaluation of a workplace bullying cognitive rehearsal program in a hospital setting. J Contin Educ Nurs. 2011;42(9):395-401.

44. Vartia M, Tehrani N. Addressing bullying in the workplace. In: Tehrani N, editor. Workplace Bullying: Symptoms and Solutions. New York, NY: Routledge/Taylor \& Francis Group; 2012:213-229.

45. Meloni M, Austin M. Implementation and outcomes of a zero tolerance of bullying and harassment program. Aust Health Rev. 2011;35(1):92-94.

46. Pate J, Beaumont P. Bullying and harassment: a case of success? Employee Relat. 2010;32(2):171-183.

47. Schwickerath J, Zapf D. Impatient treatment of bullying victims. In: Einarsen S, Hoel H, Zapf D, Cooper CL, editors. Workplace Bullying: Developments in Theory, Research and Practice. London \& New York: Taylor \& Francis; 2011:397-421.

48. Glasl F. The process of conflict escalation and roles of third parties. In: Bomers GBJ, Peterson RB, editors. Conflict Management and Industrial Relations. The Hague: Kluwer Nijhoff Publishing; 1982:119-140.

49. Zapf D, Gross C. Conflict escalation and coping with workplace bullying: a replication and extension. Eur J Work Org Psychol. 2001;10(4):497-522.

50. Zapf D, Escartín J, Einarsen S, Hoel H, Vartia M. Empirical findings on prevalence and risk groups of bullying in the workplace. In: Einarsen S, Hoel H, Zapf D, Cooper CL, editors. Workplace Bullying: Developments in Theory, Research and Practice. London \& New York: Taylor \& Francis; 2011:75-105.

51. Van de Vliert E. Moving bullies and victims up on conflict-researchers' waiting lists. Negot Confl Manag Res. 2010;3(2):87-90.

52. Podsakoff PM, MacKenzie SB, Lee JY, Podsakoff NP. Common method biases in behavioral research: a critical review of the literature and recommended remedies. J Appl Psychol. 2003;88(5):879-903. 
53. Spector PE. Method variance as an artifact in self-reported affect and perceptions at work: myth or significant problem. JAppl Psychol. 1987; 72(3):434-443.

54. Cowie H, Naylor P, Rivers I, Smith PK, Pereira B. Measuring workplace bullying. Aggress Violent Behav. 2002;7(1):33-51.

55. Escartín, Zapf, Arrieta, \& Rodríguez-Carballeira, Á. Workers' perception of workplace bullying: a cross-cultural study. Eur J Work Org Psychol. 2011;20(2):178-205.

56. Jenkins M. Practice note: is mediation suitable for complaints of workplace bullying? Confl Resolut Q. 2011;29(1):25-38.

57. Nielsen MB, Matthiesen SB, Einarsen S. The impact of methodological moderators on prevalence rates of workplace bullying. A meta-analysis. J Occup Organ Psychol. 2010;83(4):955-979.

58. Baillien E, de Cuyper N, de Witte H. Job autonomy and workload as antecedents of workplace bullying: a two-wave test of Karasek's Job Demand Control model for targets and perpetrators. J Occup Organ Psychol. 2011;84(1):191-208.

59. Beech B, Leather P. Workplace violence in the health care sector: a review of staff training and integration of training evaluation models. Aggress Violent Behav. 2006;11(1):27-43.

60. Kirkpatrick DL. Evaluation of training. In: Craig RL, editor. Training and Development Handbook: A Guide to Human Resource Development. 2nd ed. New York, NY: McGraw-Hill; 1976:18-27.
61. Jeong S, Lee BH. A multilevel examination of peer victimization and bullying preventions in schools. J Criminol. 2013;2013:1-10.

62. Duffy M, Sperry L. Mobbing: Causes, Consequences, and Solutions. New York, NY: Oxford University Press; 2012.

63. Sturdy A. Consultancy's consequences? A critical assessment of management consultancy's impact on management. $\mathrm{Br} J$ Manage. 2011;22(3):517-530.

64. Taleb N. The Black Swan: The Impact of the Highly Improbable. New York, NY: Random House \& Penguin; 2007.

65. Fattori A, Neir E, Aguglia A, et al. Estimating the impact of workplace bullying: humanistic and economic burden among workers with chronic medical conditions. Biomed Res Int. 2015;2015:1-12.

66. Salin D. Ways of explaining workplace bullying: a review of enabling, motivating and precipitating structures and processes in the work environment. Hum Relat. 2003;56(10):1213-1232.

67. Biron C, Karanika-Murray M. Process evaluation for organizational stress and well-being interventions: implications for theory, method, and practice. Int J Stress Manage. 2014;21(1):85-111.

68. Egan M, Bambra C, Petticrew M, Whitehead M. Reviewing evidence on complex social interventions: appraising implementation in systematic reviews of the health effects of organisational-level workplace interventions. J Epidemiol Community Health. 2009;63(1): 4-11.
Psychology Research and Behavior Management

\section{Publish your work in this journal}

Psychology Research and Behavior Management is an international, peerreviewed, open access journal focusing on the science of psychology and its application in behavior management to develop improved outcomes in the clinical, educational, sports and business arenas. Specific topics covered in the journal include: Neuroscience, memory and decision making; Behavior

\section{Dovepress}

modification and management; Clinical applications; Business and sports performance management; Social and developmental studies; Animal studies. The manuscript management system is completely online and includes a very quick and fair peer-review system, which is all easy to use. Visit http://www. dovepress.com/testimonials.php to read real quotes from published authors. 